\title{
Correction to: Political Spirituality for a Century of Water Wars
}

\section{Correction to:}

J. W. Perkinson, Political Spirituality for a Century of Water Wars, https://doi.org/10.1007/978-3-030-14998-7

The original version of the book was inadvertently published with incorrect gender designation in chapter 4 and missing citation and a reference in chapter 6 . The book has been updated with the changes.

The updated version of these chapters can be found at https://doi.org/10.1007/978-3-030-14998-7_4 https://doi.org/10.1007/978-3-030-14998-7_6

(C) The Author(s) 2019 https://doi.org/10.1007/978-3-030-14998-7_10 